\title{
Compare and Contrast Different Meanings of the Term World Music/World Music
}

\author{
Xueqian $\mathrm{Li}^{1}$ \\ ${ }^{1}$ The University of Kent, Kent, United Kingdom \\ Correspondence: Xueqian Li, The University of Kent, Kent, United Kingdom.
}

Received: September 27, 2019

Accepted: November 4, 2019

Online Published: November 6, 2019

doi:10.20849/ajsss.v4i4.664

URL: https://doi.org/10.20849/ajsss.v4i4.664

\begin{abstract}
With the booming popularity of the music industry today, there has been an equally increasing demand for new or refreshing music types. Over the years, this has a resulted in alternative/non-mainstream music genres gradually being accepted as popular music. To cater for the different tastes of music for consumers, in a world where advancement in technology has accelerated globalization to unprecedented levels, music Creators are producing music that have blurred the boundaries between music genres. On the other hand World Music is one that is seen by many as one which is routed in tradition. In that aspect, world music and popular music can be seen as two contrasting categories.
\end{abstract}

Keywords: world music, pop music

\section{Introduction}

Today, music that falls under the genre of world music takes up a tiny share of the music market, and only small group of audience still appreciate it. Many people just regard this genre of music as a research object in musicology department (Taylor, 1997). However, there are still some people who believe that world music plays a significant role in the development of Western popular music. Today, various popular music genres have been influenced by 'world music' although such music is not as precious and rare as music that is seen as world music. Moreover, world music is still active as a music category in the popular music market (Bohlman, 2002). This is because the music genre evolves with time and even has different meaning in different countries. World Music can even different definitions or can even be interpreted differently.

As such, this paper is divided into four parts. The information presented here has been gathered through reading, researching and the understanding of the 'world music/ World music' in the lectures. The first part of this essay focuses on analyzing the literature and critically evaluating the definition of world music from different aspects to illustrate that different countries or even regions got the different definitions of world music. The critical evaluation will be carried out through the analysis of the elements of tracks and identifying music examples that appeared to be similar in their different genre but share no connection between the geographical and cultural to understand world music well. The analysis will consider Salsa, Bhangra and Celtic music as examples. In the second part, the definition of world music will be analyzed as understood by Chinese musicology and comparing the difference of the definition of 'world music' between China and the United Kingdom. This comparison shall demonstrate that the different social and cultural background also affect the interpretation of world music. For the third part: The author introduces and states the relationship between popular music and world music. A dialectical analysis of the influence of world music in the popular music industry will also be presented. Finally, the author will expand knowledge and understanding of world music; analyze the relationship between the world music and culture, geography, and social background to draw a critical understanding of the definition of world music in the context of the popular music market.

\section{Definitions of World Music}

With the increasing influence of globalization and the development of the music industry, the emergence of mass media has changed the way people traditionally buy and appreciate music, and this has accelerated the speed of various music spreading, and people could easily to reach different types of music in different regions, and people have different understandings of the definition of world music. According to Shuk (2012) and Bohlman (2002), the term world music has been in existence for more than 20 years since its appearance. The definition of 
world music can be roughly divided into two explains in the development process: one is World music as a music category, as one of the music types that music consumers could choose, exists in the music market; the second explanation is from American musicology departments, it means music whose would not belong to the mainstream market, differs from the United States and the United Kingdom Music-type music is collectively referred to as world music. During these two definitions are both problematic and one-sided according to the research.

For example, according to Mills (2005), world music can be considered as the music whose is not belonging to Western classical or pop music. It is usually in developing or underdeveloped countries or areas. Such as Africa, Asia, Middle east and so on. It also could be called Non-western music. Traditional music in South Asia, or music in some regions, such as Latin America, can be spread to a type. But this view always has some discriminatory colors of European 'hegemonism'. However, there is another understanding. World music usually refers to some traditional regional music (Beard and Gloag, 2016) that has been mixed with Western music or added Western pop music elements. With the development of world music, there are varies of music genre be accepted and appreciated. For instance, Bhangra, Salsa, Celtic and so on. Towards the end of the nineteenth century, the culture of world music has been paid attention by musicology scholars (Cole 2006, Manuel 1988). Every time referring to 'world music' people always mention a words 'hybridity'. This word originally derived from the 17th century biology and zoology, then it was later used to describe a form of hybrid culture in which cultures were intertwined and borrowed from each other, and later used by musicologists to describe world music (Beard and Gloag, 2016). This word is a good interpretation of the characteristics of world music. Because world music is often defined as a hybrid music by combining traditional music form and popular music elements (Shuker, 2012). For example, the Salsa, Bhangra and Celtic popular music. They are all typical representatives of 'hybrid' world music. The salsa originally originated in Cuba, it became the collective name for popular music in Latin America. It covers a variety of musical styles, including: many types of samba, the bossa nova, and tango and so on (Longhurst, 2007). The lecturer Negus (2013) considered Salsa as a music genre which spans culture, politics, production and consumption, and hopes to analyze it from anthropology or sociology. Not only it draws on the musical elements of Latin America, but also incorporates American blues and jazz styles. Furthermore, the Bhangra is synonymous with Indian pop music and one of the representatives of world music (Manuel, 1988) It is a typical hybrid product that combines traditional Indian musical elements (such as traditional instruments: sitar, tabla, dhol and so on; rhythms, etc.) with electronic music production methods in Western pop music. It is reflected in the music of the Beatles' "Norwegian" and the Rolling Stones' "Paint it Black."(Longhurst, 2007). There are many types of world music like this in the popular music market, and they all prove that world music has a great influence in the popular music market.

\section{Compared With China}

In order to more comprehensively explore the understanding of people's world music, the author briefly describes the process of world music in the history of Chinese musicology from the perspective of Chinese researchers and compares the difference of world music that the Chinese understand and the United Kingdom, the United States. In the UK, there a massive sources relevant with world music. For example: 'Excursions in the world music' (Bohlman and Nettl etc., 2004); 'Worlds of music-an Introduction to the music of the world's peoples' (Titon, Cooley and Locke etc., 2009). All of them mention about the context of traditional Chinese music like: instruments, opera, or folk song. Even if the religion traditional in China be involved. However, most of them just introduced Chinese music, they regard Chinese as a part of world music then ignored 'How Chinese think of the world music?' or 'How Chinese define the world music?'. According to Stock (2009), in their book chapter 8 tried to identify the Chinese music is 'belonging' to the world music, then after his research he found that people could not just depends on the Chinese music sounds idioms (such as: 'pentatonic melody') to differ Chinese music from world music. Because just fewer music character is common or unique in the whole Chinese music. He argued that learning Chinese music is a good way to know more world music from Chinese perspective, and also is a chance to estimate the world music. Furthermore, Wong (2004), mentioned about lots of information about Chinese social backgrounds and introduced the historical and social backgrounds of different periods of music in China. This provides valuable information for introducing Chinese music, which makes it easier for researchers to understand Chinese music, and the content not only introduces a variety of music types, also involved the value and function of music in China. However, the relationship between Chinese music and world music is not be mentioned in the book. Instead, Chinese music is directly included in the part of 'World Music.' Under this assumption, people can define world music as music which does not originate from the United States or Europe. Currently, this view is not objective enough. Musician scholar Mills (2005) depends this point of view argued that World music should include all kinds of music in the world, whether it is 
combined of music from different cultures or regions, even the western classical music should be involved in world music. In addition, he emphasizes that learning world music could increase students' understanding of different cultures, and also reduce the development of 'prejudice' by acquiring knowledge (herein 'prejudice' refers to the people outside the 'western world'). This view promotes an objective understanding of the meaning of world music.

However, in Chinese ethnomusicology, culture is diversified, so world music is diversified. World music has no boundaries. Many traditional instruments have been crossed by other region cultures before. For example, in the process of the formation of 'Pipa' in ancient China, it was actually influenced by the Middle Asian region and gradually developed into a traditional Chinese instrument (Dan Xie, 2017). Therefore, the development and formation of world music stems from the blending of different cultures. In other words, world music is a manifestation of the integration of world culture (Tianxiang Xu, 2015). The well-known Chinese musicologists Renhao Yu (2013), according to the process of Chinese historical, political, and cultural development, divided the process of 'Chinese define the world music' into four parts. This explains how Chinese understanding of 'world music'. The beginning of Chinese understanding of world music from ancient of China. The instruments from Western missionaries and merchants could be used as proof that China began to know the world music. Then came the early 20th century, modern China occurred a cultural movement called the 'school songs' has been launched, which has a very important influence on the development of Chinese music, people begun to use western culture and music, then transform into Chinese music education, through singing European folk songs, but the lyrics in mandarin. After that a group of Chinese musicians go abroad then returned back to China, the number of Chinese folk music and Western music styles combined in the school music education. People thought that the 'world music' means the Western music. In the 1950s to the mid-1960s, the Chinese music community began to pay attention to the music of other Asian countries, Africa and Latin America (mainly in Cuba), some songs from these regions (Bohlman, Nettl and Turino etc., 2004). It is also widely sung in China because the songs from the third world countries could fill people's craving for lyric music to a certain extent, and also because of the need of political and cultural communicates. The music reflected the social background at that time. They understood the range of world music has expanded. In the late 1970s, the discipline of world music was officially included in the study of musicology in China. Since the 1990s, the study of 'world music' has attempted to interpret music from a cultural perspective and began to explore other nations not from European. After that the sources about ethnomusicology from European is increasingly translated into Chinese, the horizons of Chinese scholars have expanded even more. In addition, to continuing to understand the styles of classical music of all nationalities in the world, their also have more and more explanations about cultural interpretations (Bolman, Capwell, and Nettl etc., 2004). In the late 1980s, popular music from the United States affected China, and the popular music was attracted by young people. Students who studied world music gradually turned from traditional music in different countries to pop music, they studied music involved analyze music style, also attaches importance to the investigation of the social background, mode of communication of these music, and forming the research method combined with sociology (including questionnaires and statistics); until now, the meaning of world music in China is still considered to be the popular or traditional music not from China. The above is the development process of understanding and definition of the world music in China. It is quite different from the world music defined by the United Kingdom and America. It is obviously that the definition of world music relevant with the politics, economy, the social background, and the quality of the citizens. Different countries have different understandings and definitions of world music during different periods. Therefore, the meanings of the world music could be influenced by regions, country, cultures, social backgrounds, and politics (Frith, 2000). Research on world music is closely related to ethnomusicology (Fletcher 2001).

\section{The Relationship Between Pop Music and World Music}

In addition, about the relationship between the popular music with world music from historical perspective. After the end of World War II, American pop music occupies most of the music market, but most of these American pop music forms are mostly from early African traditional music. With the changes of immigration or society, these primitive rhythms are slightly processed. Later, when they returned to their hometown (Africa) in a new form, they influenced the culture that once gave birth to them and promoted the generation of world music (Negus 2013). In the 1980s, world music also showed great influence on popular music. Interestingly, this effect is a cyclical relationship: African black culture is the source of popular music. It is obviously to seen. When the black culture of slavery spread to North America, it gave birth to a root in the land of the United States. Therefore, American pop music has developed rapidly; however, when this American-style pop music returned to Africa, the first impression brought to African people was a familiar feeling, so they combination of 
traditional music elements and this re-engagement of black culture and American pop music has promoted the generation of world music. When the influence of world music in the 1980s gradually expanded, popular musicians from all over the world (especially in Asia and Africa). This is a reference to the more avant-garde contemporary consciousness through various advanced means, which in turn promotes the development of popular music. It is easily to seen that the development of world music is not isolated, is a manifestation of group consciousness and a crystallization of multiple cultures (Fletcher, 2004; Longhurst, 2007).

\section{Critical Understanding of World Music}

Therefore, in response to this phenomenon, a great deal of research has been done on world music in the popular music market. According to Dave Laing and Phil Hardy (2013), at first, in order to provide consumers with a broader consumer market, the music market sold world music as a type of music and achieved a good consumer market. However the music market has experienced a process of rapid development and change over the past 10 years, and the development of technology has accelerated the impact of globalization on the music market. In order to cater to the needs of the market, the combination of various music-type music elements and the creation of works by musicians have indirectly led to the loss of the world music market. Especially since the late 1970s, the company began through the wave of acquisitions and mergers to deal with the consumption of world music proportional reduction. As a result, more and more companies have more and more international influence, but world music as a type of music. The concept of being consumed is increasingly blurred (Scott Ed., 2016). According to Taylor (1997), his research on the world music in the music market, he believes that for the audience of world music, there are two completely opposite evaluations for world music. One of the arguments is that the development of world music has led to the loss of the music market of the traditional music type, and when the world music is produced, the various music genre will be hybridized and merged, obtained the instruments and music styles from other cultures or other countries. It is the behavior that plundering of music culture is a manifestation of hegemonism. On the contrary, another argument is that if musicians respect the music culture of other regions, they can use and promote world music, because world music has indeed sold well in the popular music market in the past year. The shrinking of the world music market is related to the way people buy and appreciate music, the cultures that consumers care about, and the policies that the government has introduced. There are many reasons for the decline in the world music market (Negus 2013; Longhurst 2007). But its existence still has influence in the popular music market, it is the inevitable music product in globalization (Beard and Gloag 2016). The existence of world music is still for ethnomusicology, musicology, music industry, and cultural studies have deep research significance.

\section{Conclusion}

In conclusion, world music is closely related to people's life. According to research, since the 1980 s, the concept of world music has been continuously improved and developed in popular music, and it has gradually become a trend of international popular music (Stobart, 2009 \& Longhurst, 1995). The development of world music is not isolated. It is the crystallization of multiculturalism. It could focus on the expression of group art. Its form is more and more diverse with the influence of globalization, but its concept has become clearer. It could be used as a record of the era (such as recording methods, performance methods and methods of dissemination), its originality and integration became its defining criteria (Taylor, 2007; Bohlman, 2002 \& Frith, 2000). So it can be said that as long as human beings do not lose the ability to live and imagine, then world music will always exist in the world of popular music. But the exact definition of world music is difficult to give because there are different understandings of world music for different countries and regions. The analysis and understanding of world music should also be multi-perspective. With the development of globalization, people will have more comprehensive explanations for world music. Its identity and culture are more and more closely related to people's lives. Its development and production are related to our society, culture, nation and market. There is a great connection, and it is worthwhile for people to conduct more in-depth and comprehensive research.

\section{References}

Beard, D., \& Gloag, K. (2004). Musicology: the key concepts (pp.121-123 \& 129-133). Routledge.

Bohlman, P. V. (2002). World Music: A Very Short Introduction: Chapter 1: 'In the Beginning... Myth and Meaning in World Music' (pp. 1-22). Oxford: Oxford University Press.

Fletcher, P. (2004). World musics in context: a comprehensive survey of the world's major musical cultures (pp.1-16 \& 31-46). Oxford University Press.

Frith, S. (2000). The Discourse of World Music. In G. Born \& D. Hesmondhalgh (Eds.), Western Music and Its Others. Berkley: University of California Press. 
Laing, D. (2009). World Music and the Global Music Industry: Flows, Corporations and Networks. Institute of Popular Music, University of Liverpool. Retrieved 21 March 2019, from https://helda.helsinki.fi/bitstream/handle/10138/25811/006_03_Laing.pdf

Longhurst, B. (2007). Popular music and society. Polity.

Manuel, P. (1988). Popular Musics of the Non-Western World: Chapter 1: 'Perspectives on the Study of Non-Western Popular Musics' (pp. 1-23). Oxford: Oxford University Press.

Negus, K. (2013). Music genres and corporate cultures (pp. 14-30 \& 152-173). Routledge.

Nettl, B., Turino, T., Wong, I., Capwell, C., Bolman, P., Dueck, B., \& Rommen, T. (2015). Excursions in world music. Routledge.

Scott, D. B. (Ed.). (2016). The Ashgate research companion to popular musicology (pp. 474-475 \& 479-481). Routledge.

Shuker, R. (2012). Popular Music Culture: The Key Concepts. See entries on 'Globalization', 'World Music', 'African-American/black music', 'Authenticity', 'Crossover', 'Appropriation' and 'Syncretism'. London: Routledge.

Taylor, T. D. (1997). Global Pop: World Music, World Markets: Chapter 1: 'Popular Musics and Globalization' (pp. 1-38). London Routledge.

Titon, J. T., Cooley, T. J., Locke, D., Rasmussen, A. K., \& Reck, D. B. (2016). Worlds of Music (Shorter Version). Nelson Education.

\section{Copyrights}

Copyright for this article is retained by the author(s), with first publication rights granted to the journal.

This is an open-access article distributed under the terms and conditions of the Creative Commons Attribution license (http://creativecommons.org/licenses/by/4.0/). 